\title{
A Conceptual Framework for Developing Student Recruitment Agents Management System Using the Balanced Scorecard
}

\author{
Keling Stevenson Boniface Ancheh \\ Curtin University of Technology \\ E-Mail: keling.stevenson@curtin.edu.my \\ Anbalagan Krishnan \\ Curtin University of Technology \\ E-Mail: anbalagan.k@curtin.edu.my
}

\begin{abstract}
The objective of this paper is to provide a conceptual framework for the development of a student recruitment agent management system for private universities and colleges in Malaysia. There is a need for such system especially in a maturing (competitive) international education market life cycle as competition intensifies. The availability of such system could provide private universities and colleges with the opportunity to develop competitive advantage through the control of the marketing channel of the international education market. This system is developed based on the balanced scorecard methodology proposed by Kaplan and Norton in the 1990s. The paper, first, analyses the nature of competition in the international education market, the role of the recruitment agents in the industry, the behaviour of the international students, and the behaviour of the recruitment agents. Next, it discusses the principal-agent theory and power theory to explain the behaviour of the agents. Apart from that, the management control theory will be used in conjunction with balanced scorecard to outline conceptual framework for the development of the student recruitment agent management system. It is hoped that this conceptual framework can be applied and tested empirically in future research.
\end{abstract}

Keywords: Student Recruitment Management System, Balanced Scorecard, Performance Management and International Education 


\section{INTRODUCTION}

Malaysia is positioning itself as the regional center for excellence in education. Currently, private universities and colleges are spearheading this initiative. Efforts are being undertaken to recruit international students from other countries in the region. These institutions are positioning itself as a low cost but high quality (value-added) providers of education, a position once held by the universities in Australia. However, a major problem faced by private universities and colleges in Malaysia, as compared to their counterparts in countries that are traditional providers of international education, is that Malaysia is a lesser-known destination for international education. Thus, to a certain extent, the positioning of these institutions does not match international students' university selection process. A study by Mazzarol and Soutar (2002) on international students' decision-making process revealed that in deciding to study abroad, students will decide on the choice of country first before making decision over the university or college. The choice of country is influenced by students' overall knowledge and awareness of the country, the level of referrals, and the cost. The choice of the university or college will be influenced by factors like reputation for quality, market profile, range of courses, alliance and coalition, offshore teaching programs, staff expertise, degree of innovation, use of IT, size of alumni base, and promotion and marketing effort (Mazzarol, Kemp \& Savery, 1997).

As prospective students choose the country first, private universities and colleges in Malaysia are at the disadvantage as relatively not much is known about the country as compared to Australia or the United States. Therefore, it is argued that the marketing of these institutions through an integrated network of the student recruitment agents can play a significant role in altering the status quo. The basis of this argument is that even currently, universities and colleges around the world are relying to a great extent on the services of the student recruitment agency. However, it is believed that at present, these institutions do not fully utilize the potentials of student recruitment agents. Maybe it is because of the traditional view that a university is not a business, and therefore a university does not market itself like a corporation. As competition intensifies among universities and colleges worldwide, a better coordination of business relationship with these agents is required. To facilitate this, an integrated student recruitment agent management system crucially needs to be developed.

The significance of this paper is that it aims to bring to light, issues pertaining to the development of the conceptual framework of this agent management system. No 
literature has been published in the area of student recruitment agent. It can be said that this area is relatively new. The methodology employed to obtain information for developing this paper was informal interviews and discussions with the staff of the marketing department of a number of private higher education institutions as well as some of the student recruitment agents. The research objectives of this paper are as follows:

1. To highlight the importance of developing a student recruitment agent management system in an increasingly competitive international education environment,

2. To provide the conceptual framework for the development of the system, and

3. To explore the use of the balance scorecard methodology for developing the system.

\section{MATURING INTERNATIONAL EDUCATION MARKET}

There has been a significant drop in the growth rate of international students studying abroad brought about by the globalisation of the education industry and the changing global economic landscape (Mazzarol \& Hosie, 1996). As the high economic growth of the ' 90 s in the Asian economy triggered the expansion of the middle class community, the demand for higher education increased in excess of the country's capacity to cater for such demands. In addition, the rising cost of education abroad due to imposition of various fees resulted in the decline in funding from the governments to universities (Kemp, 1990). This has created tremendous supply opportunities to the local entrepreneurs and educationalists. The demand for an expansion in the local supplies of quality higher education was further enhanced following the 1997 currency crisis. Devaluation of the currencies of affected countries fuelled further demands for local expansion of education providers.

On the supply side, the advances in the information and communication technologies provide opportunities for traditional suppliers of international education to expand into the Asian economies through forward integration. The changes in government regulations and policies to attract high quality international education providers to expand into their respective country facilitated the forward integration. These forward integrations are shaped by competitive factors driven by the motivation to attain the share of student numbers from the international market (Saffu \& Mamman, 2000). Eroding competitive advantage (high cost) is also another push factor in this strategy. These changes are indications that the international education market is moving 
into the maturity phases of the life cycle (Mazzarol \& Hosie, 1996).

\section{OVERVIEW OF MALAYSIA PRIVATE HIGHER EDUCATION SYSTEM}

Since the 1960s the limited capacity of its domestic higher education institution has rendered Malaysia to rely on universities and colleges overseas to develop its human capital needs. Increasingly, privately sponsored students as well as government sponsored students were sent overseas to attain their higher education while efforts were also in place to expand the capacity of the domestic institutions. For varying reasons, students tended to choose English speaking countries such as the US, UK, Australia, Canada and New Zealand as the study destinations (Mazzarol \& Soutar, 2002). The rapid economic growth experienced by Malaysia since 1980s was partly attributable to the heavy investment in developing its human resource capital as the economy was increasingly being integrated with the economy of the rest of the world. During this period, private colleges began to mushroom around the country positioning themselves as the alternative source of higher education, offering awards of Certificate, Diploma and Professional body qualification, as well as Bachelor degrees in collaboration with foreign universities on Twinning and Credit Transfer Arrangement (The Malaysian Education System: Overview of Public and the private Education, 2004). The extensive links with these foreign universities as well as the rising cost of going overseas to study enhanced the attractiveness of these private colleges to move towards medium-to-high technology industries, further development and investment in skilled labour were essential to meet the professional and technical skills requirements of the economy. The rising cost of overseas higher education as a result of the reform and the adoption of the user-pay concept in Western universities rendered the country to expedite the expansion of its domestic capability to meet its education needs (Tan, 2002). This led to the restructuring of higher education sector in Malaysia through a plan to position Malaysia as the regional centre of educational excellence (Kasim, 2001). This is described by Rudner (1998, p. 91 cited in Philips \& Stahl, 2000) as a "two-pronged strategy" that aims at expanding the domestic university and college systems to meet the domestic educational needs, as well as opening up to participate in the international trade in higher education services. Towards this end, the Malaysian government enacted six Acts within the two years in 1995 to 1997 to reform the overall education sector (The Malaysian Education System: Overview of Public and the private Education, 2004). These Acts are:

- Education Act, 1996 
- Private Higher Educational Institutions Act, 1996

- National Council on Higher Education Act, 1996

- National Accreditation Board Act, 1996

- Universities and University Colleges (Amendment) Act, 1996

- National Higher Education Fund Board Act, 1997

Prior to the restructuring, Malaysian private higher education sector was characterized only by the private colleges. As a result of these Acts, in addition to the mushrooming private colleges offering twinning programs with overseas institutions, private universities can be set up and foreign universities at the invitation of the government may establish their branch campuses in Malaysia. These Acts also allow for the recruitment of foreign students as well as teaching staff. This is to ensure that these institutions can produce a competent workforce equipped with the skills, knowledge, attitude and behaviour to meet the demands of the high-technology era as well as internationally recognized qualification. As at 31 December 2003, there were 76,505 students enrolled in Malaysian private universities while 237, 839 students were enrolled in Malaysian private colleges. As at the same period of time there were 525 colleges and 24 universities in Malaysia (The Malaysian Education System: Overview of Public and the private Education, 2004). The post-restructuring period of the private higher education sector in Malaysia sees the establishment of private universities and branch campuses of foreign universities. A number of private colleges are allowed by the government to offer full foreign universities degree programs. This period effectively characterises Malaysian private higher education sector into two categories of institutions namely private colleges and private universities.

Private colleges are often more established since some of them have been in existence since the 1980s. These institutions are often seen as small providers of higher education as compared to private universities although they are of varying sizes in terms of capital, premises, the facilities and the range of courses offered. Despite its relative sizes, private colleges are the major players in the industry. These colleges have continued to attract 237,839 foreign and local students although only 26 private colleges (out of 525) are approved by the Malaysian government to offer the $3+0$ foreign university bachelor degree programs in Malaysia. On the other hand, private universities are made up of universities and university-college established and owned by financially sound corporations in Malaysia, whereas foreign universities branch campuses are 
backed by financially sound local partners or government agencies (The Malaysian Education System: Overview of Public and the private Education, 2004). Overall, these institutions can be seen as the big players in the industry and can have the advantage as compared to private colleges in terms of the awards, premises, facilities, services and market outreach.

\section{PROBLEMS ASSOCIATED WITH RECRUITMENT AGENTS}

Currently, there are major problems associated with student recruitment agents. Specifically, these are:

1. Unethical practice by recruitment agents in recruiting students, ,

2. Lack of loyalty to the institutions that engage them as recruitment agents,

3. Lack of proactive promotion for the university they are representing.

These problems would be addressed by developing student recruitment agent management system. The balanced scorecard framework developed by Robert and Kaplan in 1990 is used for this purpose. However, first, the behaviour and other characteristics of the recruitment agents must be understood.

\section{RECRUITMENT AGENT BEHAVIOUR USING THE PRINCIPAL-AGENT THEORY}

The issue with the student recruitment agents concerns with the means of getting these agents to act in the best interests of the university or college. However, the latter has limited means to monitor and to control the following activities:

(1) To ensure that agents exert their optimum efforts to act on behalf of the university, and

(2) To ensure that agents recruit the students ethically.

Very often agents tend to portray inaccurate picture of the universities and colleges that they are representing (Mazzarol \& Hosie, 1996), or they may instead promote other universities and colleges because of higher percentage of commission or greater foreign exchange rates (moral hazard). The incentive for the agents to do the above is because their main interest is to make as much profit as possible. This creates major problem to universities and colleges both in short and long term. Therefore, to solve this problem, the rewards and incentives structure for the agents must be designed in a manner such 
that the interests of the agents can be aligned with the interests of universities and colleges.

\section{POWER CONSIDERATION IN THE PRINCIPAL-AGENT RELATIONSHIP}

In developing the rewards and incentives structure of student recruitment agent management system, the use of power in enhancing cooperation between universities and colleges (principals) and student recruitment agents must also be taken into account (Quinn \& Doherty, 2000; Falbe \& Danridge, 1991; Wilkinson, 1996). It is important to understand the concept and sources of power in order to understand the means in which the principal can change or modify the behaviour of the agents or vice versa (Hunt \& Nevin, 1974; Quinn \& Doherty, 2000). Generally, the power of the principal lies in the brand name of its products or services. The more positive the recognition of the brand is the stronger is the power of the principal. In contrast, the power of the agents rests on their market knowledge and expertise. The greater the intensity for competition is, the greater the power of the agents is over the power of the principal. In this case, as the international education industry is in the maturity stage of the industry life cycle, the power of the student recruitment agents is seen to be stronger than that of the universities.

In managing the relationship with the recruitment agents, universities and colleges can exercise the use of coercive power (punishment and reward) should any conflict arise (Wilkinson, 1996). The contract that governs the principal-agent relation tends to place greater power to the principal rather than the agents. However, in a maturing market environment where the power of agents is seen to be strong, the use of coercive power may dissatisfy the agents and hence can result in poor relationship and poor coordination (Quinn, 1998). Instead, the use of non-coercive power is more appropriate. Universities

and colleges can obtain the non-coercive power by providing supports and management by persuasion and example (Hunt \& Nevin, 1974). The result of using non-coercive power will satisfy the agents and thereby make it easier for universities and colleges to control and to influence the behaviour of the agents. This is very critical for universities and colleges given that students' decision-making process would give priority to the choice of country rather than university. Compared to the traditional providers of international education services, universities and colleges do not have this advantage. Hence, the agents must be motivated and induced by universities and colleges to market to students by emphasizing the benefits of considering the institution, instead of by country. 


\section{APPROACHES OF CONTROLLING THE BEHAVIOUR OF THE AGENTS}

In designing the control aspect of the student recruitment agent management system, two major control approaches must be evaluated. There are two basic control approaches, namely the 'after-the-fact' control and 'before-the-fact' control (Thompson, 1998). These are incentive based approaches. Compensation of recruitment agents based on commission is an example of 'after-the-fact' control approach. Recruitment agents are paid according to the number of students they have recruited for the university. This approach should be retained but it needs to be reinforced, as it does not have any mechanism to determine whether the recruitment agents have recruited the students ethically or not. On the other hand, 'before-the fact' control approach is designed to direct the agents to behave in certain behaviour. This approach requires setting the target and predetermining the desired behaviour to achieve the target. It is appropriate to use this approach where the results may vary, unique and are hard to measure. In the case of private higher education institutions, to induce the recruitment agents to behave ethically and to carry out the marketing activities to achieve the long-term goals, it is necessary to use 'before-the-fact' approach. Therefore, both 'after-the-fact' and 'before-the-fact' approaches should be used to control and to manage the recruitment agents.

The development of this student recruitment agent management system must also include the following elements:

1. Recruitment agents would have to provide their marketing plan including the types of promotional activities that they plan to undertake and the targeted numbers of students to be recruited. The plan may show, for instance, a reduction in advertisement expenses but an increase in promotional activities that take into account both short-term and long-term objectives.

2. The institution must provide financial and non-financial supports to implement these marketing and promotional activities. The power of the recruitment agents must be considered in this situation in that the agents must be supported to satisfy them so that they find it beneficial to give strong support to the institution and to develop a strong bond.

3. The agents must be provided with the appropriate training skills to promote and sell the services of the institution.

4. On-line reporting mechanism must be established to allow quick reporting and information exchange.

5. An incentive or reward structure must be developed to take into account the use of 'after-the fact' and 'before-the-fact' control approach. Reward structure should 
have the following characteristics:

a. Incremental percentage of commission relative to the number of student recruited.

b. Bonus awarded for achieving non-financial, long-term target and areas of continuous improvement.

\section{LINKING THE BALANCED SCORECARD TO STUDENTS RECRUITMENT AGENTS MANAGEMENT SYSTEM}

The balanced scorecard developed in the early 1990s by Robert Kaplan and David Norton can be used to develop the recruitment agent management system. Balanced scorecard is an effective management control system. According to Simons (1991, cited in Olson \& Slater, 2002, p. 11), management control system has three major elements: (a) setting performance standards, (b) measuring performances against the standards, and (c) taking corrective action if the standard is not achieved. They further assert that this system provides feedback on the effectiveness of competitive activities, enables learning from internal and market-oriented experiences and provides guidance for strategic change and renewal. The balanced scorecard incorporates all the elements of management control system as noted by Simons (1991, cited in Olson \& Slater, 2002, p. 11).

The balanced scorecard is not only a management control system. It can also be used as a strategic management system to set goals and the required action plans at all level of the organization. Additionally, it can be used as the information communication system to communicate these goals and action plan as well as a learning system to improve performance to attain higher goals. The application of balanced scorecard as the basis of developing student recruitment agent management system allows the objectives and measurements to be set for the agents to achieve the principal's vision in terms of the number of students recruited. Continuous review process is undertaken to close the gap between the actual achievement and the blue print in the balanced scorecard strategy map. Thus, the application of balance scorecard in student recruitment agent management system serves both functions: as a control system to evaluate the agents' performance and as the strategic tools to articulate business strategies to achieve a common goal of the principal and the agents.

The strategy and measures developed using the balanced scorecard also emphasise on the long-term key performances drivers of success to balance the traditional short-term strategy and measures. The strategy is formulated base on a set of hypotheses of cause 
and effect relationship. The cause and effect relationship is best expressed by using ifthen notion. For example, the principal establishing a link that provides training to agents will ultimately improve the recruitment of international students. The cause and effect relationship for this link is expressed as follows:

- If the principal increases training about product, then the agents' product knowledge is improved.

- If the agents' product knowledge is improved, then the agents can provide effective recruitment services.

- If recruitment services are improved, then the principal will be able to attract international students through agents.

- If the international students choose to study at principal institutions, then both the principal and agents will benefit from financial gain.

Thus, cause and effect relationship is a foundation to construct a proper scorecard system that translates the strategy into action plan. According to Kaplan and Norton (1996), the chain of cause and effect should pervade all four perspective i.e. Financial, Customer, Internal Business process and Leaning and Growth, of a Balanced Scorecard.

Each business is unique and therefore it requires different set of the cause and effect relationship. As mentioned above, in terms of principal agents relationship, the power of principal lies in the brand name and of its products, while the power of the agent lies on the their market knowledge and expertise. Brand name and market knowledge are fundamental strategy tools to attract customers to acquire the principal's services. Thus, in the context of principal and agents relationships a great emphasis is placed on customer perspective. The objectives and the performance drivers that are identified in other perspectives of the balanced scorecard, namely financial, internal business and learning and growth perspectives, will further enhance the customers' perspective. A point to be noted that the "internal business process perspective" name is changed to "business planning perspective" to suit the nature of principal and agents' business relationship, the details are discussed in the following sections. The cause and effect relationship of these four perspectives for the student recruitment agent management system is illustrated in the balance scorecard strategy map figure 1. 


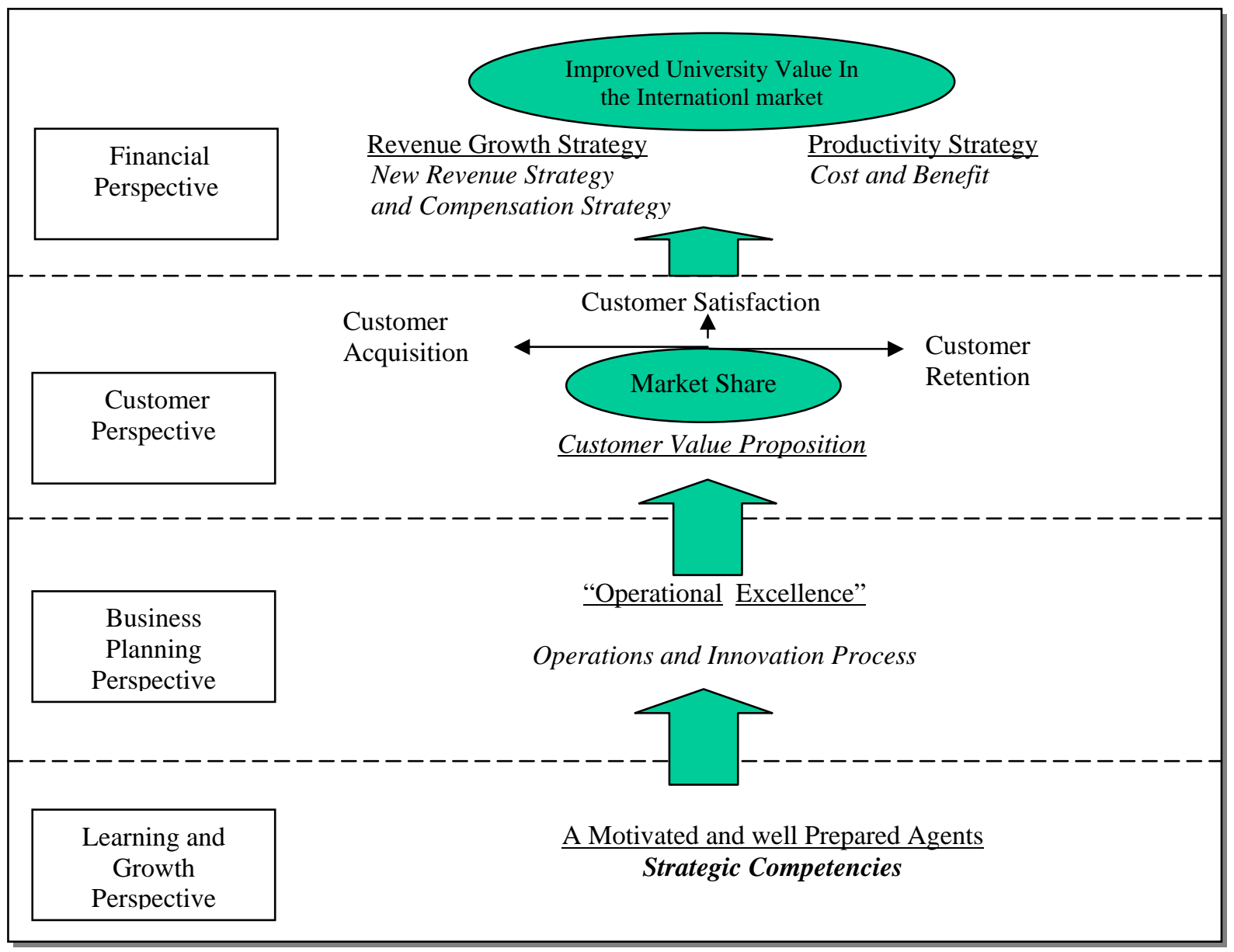

Figure 1 BSC Strategic Map for Recruitment Agents System

\section{ANALYSIS OF EACH BALANCED SCORECARD PERSPECTIVE OF RECRUITMENT AGENTS MANAGEMENT SYSTEM}

\section{Financial Perspective}

The ultimate aim of this perspective is to improve the university's values in the international market and indirectly promoting the country's name. Agents who have vast market knowledge and direct relationship with customers particularly in international market, contribute largely to the improvement of the university's values. In the financial perspective, the agent recruitment activities are evaluated based on the revenue growth strategy and product strategy. The financial objective of revenue growth strategy is a market growth in new market segments as well as the maintenance of student recruitment in the existing market. The measurements for this objective are sales growth in specific 
market segments and return on investment. The increase in university's values, which in return will improve the stakeholders' values, are measured through student growth in a particular international market. The growth in student number is the major determinant of improvement in the principal's brand image, which is the university's intangible asset, is also known as goodwill. Improvement in the university's intangible value is measured through an increase in share value and an increase in revenue margin. Research reveals that improvements in intangible assets affect financial outcomes through chains of causeand-effect relationship involving two or three intermediate stages. For example, better service quality leads to higher customer satisfaction, higher customer satisfaction leads to increased customer loyalty and increased customer loyalty generates increased revenues and margins (Huselid 1995; Becker \& Huselid 1998, cited in Kaplan \& Norton, 2001, p. 88).

Compensation is another important component of revenue growth strategy because it is a major driving force to motivate recruitment agents to contribute to a growth in revenue. The financial objective of this perspective is whereby the agents are compensated reasonably and adequately for the efforts of recruiting international students. Therefore, the financial and non-financial rewards should be appropriately tied to recruitment agent management system. "After-the-fact" financial rewards are common traditional compensation control system awarded to recruitment agents. The use of "before- the-fact" approach, whereby the agents are required to set the target and strategy prior the recruitment and principal provide them with the appropriate financial support, is an effective financial control measurement which allows the principal to monitor the agent's performance. This system also enables the principal to assist agents to close the gap between actual performances and planned activities, and the strategy to close this gap is systematically planned in business planning perspective. In addition, a bonus reward system can also be incorporated in the agent performance. This is an additional reward awarded to agents for successfully recruiting students above the target numbers. This is to compensate for the extra efforts and also to ensure continuous supply of a bigger number of students in the future. Furthermore, this kind of additional reward payment will certainly improve the agents' loyalty to stay longer with principal and be exclusive to promote only principal services. Additional non-financial rewards that can be used include certificate of job recognitions or gift vouchers.

On the other hand, the productivity strategy focuses on cost and benefits of recruitment agents. The financial objective of this perspective is reducing both direct and 
indirect costs incurred by principal on behalf of agents promoting the principal products. Like all other business, the cost must be at minimum level and at the same time the revenue is maximised. For example, the advertisement cost incurred by principal in order to help with the agent recruitment process must be justified with benefits. The benefits are evaluated through a common financial measure that analyses the cost and the number of students recruited by the agents, such as 1) unit cost per transaction, 2) cost per students to provide information, 3) and cost comparison percentage with other identical agents at identical location. All these financial measurements provide effective measurement of agents' performance as well as cost and benefit justification.

\section{Customers Perspective}

Serving the needs of the customers and providing satisfactory services are the core aims of every business. The principal has given a responsibility to agents to act on behalf of the university to recruit the students. However, agents have complete authority to persuade students to any favorable institutions as per their preference not as per student's preference. In the context of customer perspective, the agents hold stronger power as opposed to principal's in influencing the customer's decision. Agents' decision is mainly influenced by attractive financial promised by principal. With this in mind, the agents may attempt to influence the customer's decision by giving inaccurate information and recruiting the students' unethically. Therefore, a well formulated strategy and measure of recruitment agents are required to ensure the customers are satisfied with agent's services and that they are given true information about the principal's services.

The customer's value propositions are the key measurement of customer's perspective. According to Kaplan and Norton (1996) customer's value propositions represents the attributes that supply companies provide through their product and service to create loyalty and satisfaction in targeted customer segments. In addition to these, the image and customer relationship are also important components of customer's value propositions (Kaplan \& Norton, 2001). Certainly in the context of principal and agent relationship which governs the recruitment agent management system, a customer satisfaction, good customer relationship and brand image are achieved through agents. Therefore, the key measurements of customer's value propositions are customer satisfaction, customer retention and customer acquisition. These are the key indicators of agents' performance. Such measurement is crucial to ensure the brand name of principal is not tarnished due to agents' unethical behavior and unsatisfied services which both 
have impacts on principals' intangible asset value.

The second attribute of customer's value propositions is customer retention, which refers to a desirable way for maintaining, or increasing market share in targeted customer segments by retaining existing customers in those segments (Kaplan \& Norton, 1996). For example, agents recruiting students from China must create a good brand image of the principal in order to maintain the continuing preference of the principal by students from China. Example of the performance indicator for customer retention is the rate of percentage increase in student intake from specific international market segments. The increase in student growth could only be achieved through satisfactory services by the agents, which includes providing accurate information about principals. This is because the existing students may feed the market with information which, if differs from the agents', will have negative impacts on future students' enrollment. Therefore, an analysis of student intake of a particular international market is a key performance indicator of customer retention.

The final attribute of customer's value propositions is customer's acquisition, which refers to customer's recruitments from new business segments, i.e. international market. The customer's acquisition could be measured by either the number of new students recruited or the total sales in new business segments (Kaplan \& Norton, 1996).

\section{Business Planning Perspective}

The internal business perspective focuses on internal business processes to deliver the objectives of customer and financial perceptive. However, in the context of the student recruitment agent, this internal business processes are under the control of agents and the principal has minimum influence. Nevertheless, the principal can only be involved in the strategy and marketing planning, to assist agents in achieving the objectives of the first two-balanced scorecard perspectives. Hence, for the purpose of the student recruitment agent management, the "internal business perspective" of the balanced scorecard is changed to "business planning perspective" to reflect the principal involvement in agents' strategic recruitment planning.

Also in this context, business planning perspective focuses on operational excellence and innovation strategy. As in operational excellence, the agents' performance is monitored based on their existing operational recruitment strategy rather than internal business process. This strategy includes recruitment activities, such as the number of visits made to schools per year, the number of seminars organized in year, the number of 
career talks conducted in year and the effectiveness of these activities measured by monitoring the increase in students registration in that particular year. However, the effectiveness of this kind of recruitment activities is questionable. According to Kaplan and Norton (1996) this kind of operational recruitment measurements are classified as a traditional approach, which differs from the balanced scorecard approach. The balanced scorecard approach will usually identify a new process at which the organization must excel to meet customers' and financial objective (Kaplan \& Norton, 1996). In a very competitive business environment and particularly in the era of globalization, the agents must consider a new process of recruiting the students, otherwise the possibilities of others taking their share of market is very high. A new process as in recruitment management system refers to innovation in the process of recruiting customer. Innovation in the recruitment strategy is necessary to penetrate or win a new business international market. Thus, the operational excellence measurement is only good for customer retention in existing market; however, for customer acquisition in new market, an innovation strategy is necessary. As noted by Kaplan and Norton (1996), the traditional performance measurement systems focus on the processes of delivering today's products and services to today's customers. However, to meet long-term financial success requires a strategy incorporating innovation and the related measurement.

In business planning process perspective, the student recruitment agents are evaluated based on both approaches that are operational excellence (their existing recruitment strategies and how effective it's being delivered) and innovation process (innovation strategy in recruiting the potential customers). The measurements used for operational excellence are sales satisfaction survey and increase in student intake. On the other hand, for innovation, the agents' performance is measured based on market leadership securing a new business in international market. Market leadership refers to market share in all major international market, the number of new strategy recruitment developed to meet new demands as well as existing customers' request and requirement (Chow et al., 1997).

\section{Learning And Growth Perspective}

The learning and growth perspective strategies are set based on the other three balanced scorecard objectives for continuous successful performance by recruitment agents. This means that any performance gap in financial, customer and business-planing

perspectives is closed by identifying an appropriate strategy in this last balanced 
scorecard perspective. For example, if customers' satisfaction under the customer perspective is found to be poor, the causes will be identified and relevant remedies are offered under the learning and growth perspective. Besides identifying the strategy, in this perspective the agents also need to define the employee's capabilities and skills as well as the technology and corporate climate that are needed to support a selected strategy (Kaplan \& Norton, 2001). As such, the main focuses of learning and growth perspective are strategic competencies.

Strategic competencies refer to the aspects of competencies and skill possess by human resource of recruitment agents to meet the principal goals. The objective of this perspective is to ensure that staffs at recruitment agents possess the right skills to offer effective and efficiency recruitment services. As such, strategic competencies refer to staff development system to develop its human resource capabilities and skills. Performance measurements such as a number of strategic meetings with principal, a number of workshops participated by agents to improve its student recruitment skills either with principal or with other professional trainers will indicate the agents' seriousness in achieving the principal's business mission. The ultimate aims of this measurement are to make sure that the recruitment agents continually improve their capabilities in providing excellence and accurate service on behalf of the principal. After addressing strategic objective in learning and growth perspective, it, then, provides a complete strategy map and linkages to all other three perspectives.

\section{CONCLUSION}

In a matured international education market characterized by intense competition among universities, the competitive edge would be for the universities and colleges to change the rule of the competition and the perception of the market. Within this context, universities and colleges are in a favorable position to have the competitive edge in the matured international education market because they are low cost providers of high quality education. At the same time, as new university campuses currently in the process of establishing themselves, competitive position without much rigidity of the tradition can retard their growth. However, to be able to do that, universities and colleges will have to re-engineer its relationship with their recruitment agents into a more integrate marketing channel through the use of a properly defined recruitment agent management system. Incorporating the balanced scorecard into the agent recruitment management system to formulate strategies which focus on reward structure and the enforcement of 
the marketing plan and targets, a system can be developed for empirical testing. Based on above discussion of linking each balanced scorecard perspective into the agent management system, it is proposed that following proposition to be used for future empirical test (Appendix 1 provide the summary of the objective and measurement of each perspective that will be discussed in the following propositions).

Proposition 1: The balanced scorecard based students recruitment agent management system will improve the university's finance as well as the university's values in the international market.

Proposition 2: The balanced scorecard based student recruitment agent management system will prevent the agent from recruiting students unethically by providing inaccurate information due to financial attraction provided by the principal.

Proposition 3: The balanced scorecard based student recruitment agent management system will provide universities and colleges with competitive and innovative tools to be ahead of their competitors.

Proposition 4: The balanced scorecard based student recruitment agent management system will help on improving the agents' recruitment skills and subsequently help to promote good brand name and image of the universities or

In summary, linking balanced scorecard methodology to the student recruitment agent management system provides a valuable management control system. This also helps to overcome the issue of monitoring, as highlighted in the principal-agent theory. Therefore, the balanced scorecard can become a powerful tool for developing the student recruitment agent management system.

\section{REFERENCES}

Chow,C.W, Kamal.M.H. \& James,E.W. (1997). Applying the Balanced Scorecard to Small Companies, Management Accounting, 79(2), 21- 27.

Falbe, C.M., \& Danridge, T.C. (1991).Franchising as a strategic partnership: Issues of cooperation and conflict in a global market, International Small Business Journal, 10(3), 40-52.

Hunt, S.D., \& Nevin, J.R. (1974). Power in a channel of distribution: sources and consequences, Journal of Marketing Research, 11, 186-93.

Kaplan, R.S., \& Norton, D.P. (1996). Linking the Balanced Scorecard to Strategy, California Management Review, 39(1), 53 - 79.

Kaplan, R.S., \& Norton, D.P. (2001). Transforming the Balanced Scorecard from 
Performance Measurement to Strategic Management: Part 1, Accounting Horizon, 15(1), $87-104$.

Kassim, A. (2001). Malaysia as a Centre of Education: Excellence: Experience and Plan, 15th Australian International Education Conference.

Kemp, S. (1990). Exporting Higher Education-International Flow of Students, Curtin School of Economics and Finance Working Paper Series, no. 90.

The Malaysian Education System: Overview of Public and Private Education. (2004). Retrieved: July 20, 2004, from http://www.studymalaysia.com/is/smh4_chap1.shtml.

Mazzarol, T., \& Hosie, P. (1996). Exporting Australian Higher Education: Future Strategies in a Maturing Market, Quality Assurance in Education, 4(1), 37-50.

Mazzarol, T., Kemp, S., \& Savery, L. (1997). International Students Who choose not to study in Australia: An examination of Taiwan and Indonesia, Australia International Education Foundation, Camberra.

Mazzarol, T., \& Soutar, G. N. (2002). Push-pull factors influencing international student destination choice, The International Journal of Educational Management, 16(2), 8290.

Olson, E.M., \& Slater, S.F. (2002). The Balanced Scorecard competitive strategy, and performance, Business Horizon, pp.11-16.

Phillips, M.W., \& Stahl, C.W. (2000). International Trade in Higher Education Srvicesin the Asia pacific Region: Trends and Issues, Pacific Economic Cooperation Council (PECC), Human Resource Development Task Force, 9th Annual Meeting, 21-22 October, Hualien, Chinese Taipei.

Quinn, B. (1998). The internationalization process of a franchise system: An enthnographic study, Asia Pacific Journal of Marketing and Logistics, 10(2), 66-84.

Quinn, B., \& Doherty, A.M. (2000). Power and control in international retail franchising -Evidence from theory and practice, International Marketing Review, 17(4/5), 354-372.

Saffu, K., \& Mamman, A. (2000). Contradictions in international tertiary strategic alliances: the case from down under, The international journal of public sector management, 13(6), 508-518.

Tan, A.M. (2002). Malaysian Private Higher Education: Globalization, Privatization, Transformation and Marketplaces, Asean Academic Press, London.

Thompson, F. (1998). Public economics and public administration, Handbook of Public administration (2nd ed.). New York: Rabin and Miller, Inc. 
Wilkinson, I.F. (1996). Distribution channel management: power consideration, International Journal of Physical Distribution \& Logistics Management, 26(5),31-41

\begin{tabular}{|c|c|c|}
\hline $\begin{array}{r}\text { Summary of The } \mathbf{O} \\
\text { Stud } \\
\end{array}$ & $\begin{array}{l}\text { tives And Measuremer } \\
\text { Recruitment Agent Ma }\end{array}$ & $\begin{array}{l}\text { s of The Balanced Scorecard of } \\
\text { lagement System }\end{array}$ \\
\hline Perspective & Objective & Measurement \\
\hline $\begin{array}{l}\text { Financial Perspective } \\
\text { Revenue growth strategy }\end{array}$ & $\begin{array}{l}\text { 1) Market growth in new } \\
\text { market segments } \\
\text { 2) Maintaining the existing } \\
\text { market segments } \\
\text { 3) Increase in university } \\
\text { value in international } \\
\text { market i.e. intangible } \\
\text { assets. } \\
\text { 4) Agents are compensated } \\
\text { reasonably and } \\
\text { adequately }\end{array}$ & $\begin{array}{l}\text { Sales growth percentage. } \\
\text { Return on investment. } \\
\text { Students' growth percentage. } \\
\text { Increase in university share value. } \\
\text { Increase in revenue margin. } \\
\\
\text { After the fact. } \\
\text { Before the fact. } \\
\text { Bonus system. } \\
\text { Non-financial compensation. } \\
\text { Number of students recruited. } \\
\text { Cost per students. } \\
\text { Cost per transaction. } \\
\text { Cost comparison percentage. }\end{array}$ \\
\hline $\begin{array}{l}\text { Customer Perspective } \\
\text { Customer value propositions. }\end{array}$ & $\begin{array}{l}\text { Customer satisfaction } \\
\text { Customer retention } \\
\text { Customer acquisition }\end{array}$ & $\begin{array}{l}\text { Survey on existing students. } \\
\text { Number of complaints. } \\
\text { Percentage increase in student intake from } \\
\text { existing market. } \\
\text { Number of new customer recruited. } \\
\text { Total sales to number of customers in new } \\
\text { business segments. }\end{array}$ \\
\hline $\begin{array}{l}\text { Business Planning } \\
\text { Perspective }\end{array}$ & $\begin{array}{l}\text { Operational excellence } \\
\text { (which objective includes } \\
\text { innovation promoting the } \\
\text { principal's product) }\end{array}$ & $\begin{array}{l}\text { Business planning evaluation. } \\
\text { Sales satisfaction survey. } \\
\text { Market leadership in a new business } \\
\text { segments. } \\
\text { New recruitment strategy. } \\
\end{array}$ \\
\hline
\end{tabular}




\section{Summary of The Objectives And Measurements of The Balanced Scorecard of} Students Recruitment Agent Management System (Continued)

\begin{tabular}{|l|l|l|}
\hline Perspective & Objective & Measurement \\
\hline $\begin{array}{l}\text { Learning and growth } \\
\text { perspective. }\end{array}$ & $\begin{array}{l}\text { Continuous successful } \\
\text { performance by agents. }\end{array}$ & Strategy recruitment workshop. \\
$\begin{array}{l}\text { Agents' staff well trained to } \\
\text { offer effective and efficient } \\
\text { recruitment services. }\end{array}$ & Continuous staff development activities. \\
\hline
\end{tabular}

